\title{
THE INFLUENCE OF ENVIRONMENTAL FACTORS ON EMPLOYEE COMFORT BASED ON AN EXAMPLE OF LOCATION TEMPERATURE
}

\author{
I. SZER ${ }^{1}$, E. BLAZIK-BOROWA ${ }^{2}$, J. SZER ${ }^{3}$
}

\begin{abstract}
Work in unfavorable, changing environmental conditions negatively affects people working on scaffoldings used on construction sites, which may increase the risk of occurrence of dangerous situations. The purpose of this article is to show the scale of temperature changes which workers are exposed to. The paper compares examples of temperature measurements obtained from a metrological station and during tests on scaffoldings located in the Lodz and Warsaw regions. This article also presents the methodology of examining environmental parameters of the surroundings where employees work on scaffoldings. Analysis results show that high temperatures and significant temperature variations frequently occur on the scaffoldings, which leads to a lack of adaptability and consequently to tiredness or decreased alertness. Unfavorable environmental conditions can lead to behaviors which, in turn, can cause accidents.
\end{abstract}

Keywords: scaffoldings, safety, temperature

\section{INTRODUCTION}

Our natural environment contains many variable factors affecting the human body, one being temperature. Work in unfavorable, dynamically changing conditions can reduce workers' motivation, concentration, and psychomotor performance, and can induce physiological functions changes in the

\footnotetext{
${ }^{1}$,PhD., Eng., Lodz University of Technology, Faculty of Civil Engineering, Al. Politechniki 6,00-637 Lodz, Poland, e-mail: iwona_s@p.lodz.pl

${ }^{2}$ Prof. LU. DSc., PhD., Eng., Lublin University of Technology, Faculty of Civil Engineering and Architecture, ul. Nadbystrzycka 40,20-618 Lublin, Poland, e-mail: e.blazik@pollub.pl

${ }^{3}$ PhD., Eng., Lodz University of Technology, Faculty of Civil Engineering, Al. Politechniki 6, 00-637 Lodz, Poland, e-mail: jacek.szer@p.lodz.pl
} 
human body [1]. Additionally, if a worker performs a job which requires increased physical activity, this can lead to an individual accident or even a construction disaster. Work-related accidents involve human losses, ranging from light injuries to even death, as well as economic losses. The average cost of a serious accident which a company incurs is 213470 PLN, when the preventive measures cost preventing the accident is 1712 PLN. This cost is disproportionately low in relation to the cost which must be incurred whenever an accident occurs [2]. Therefore, it is very important to anticipate the risk of a too low or too high temperature to ensure safe and efficient work conditions. Temperature influence on human behavior is the subject of research across different disciplines. Studies have shown that the optimum temperature ranges from $17{ }^{\circ} \mathrm{C}$ to $21{ }^{\circ} \mathrm{C}$ [1]. Significant decreases of temperature can cause hypothermia and, on the other hand, significant increase can cause overheating. Outdoor work in below-freezing conditions, at temperatures below $0{ }^{\circ} \mathrm{C}$ with an air flow of $3-4 \mathrm{~m} / \mathrm{s}$ causes a great loss of heat, cools the whole body, and affects the face and hands causing local skin damage in the form of cracks and frostbite. Cold environments can lead to a decrease of temperature in the muscles, resulting in a reduced ability to exert physical effort and in increased reaction times [3]. In turn, higher environmental temperatures can cause an increase in internal temperature. With an unbalanced system, the increase of body temperature by $1{ }^{\circ} \mathrm{C}-1.5^{\circ} \mathrm{C}$ affects most organs, and, mainly, the circulatory system. Physical work during high temperatures also affects the central nervous system. Possible symptoms to watch for are, for example, increased irritability or apathy, indifference, prolonged reaction times. This effect is smaller when the persons are first acclimatized to their environment[1].

In the U.S., scientists have presented isodecrement curves for the probability of adverse event occurrences for variable temperature conditions, showing that the temperature above which an accident increase is observed is radically different for varying types of tasks and decreases with the decrease of the duration of a given task. For light work carried out by employees without acclimatization, this temperature is about $29{ }^{\circ} \mathrm{C}$, and for workers previously acclimated it is $32{ }^{\circ} \mathrm{C}$ [4]. Higher temperatures cause a gradual increase of body temperature, which - up to some point improves efficiency, but is also associated with higher human energy loss.

Temperature also has an impact on work efficiency. In current literature, examples have been compared illustrating decreases in labor productivity in both low and high temperatures according to WBGT (Wet Bulb Globe Temperature) [5]. The highest decrease in productivity (14.88\%) was observed in the case of people working at high temperatures (above $32.2{ }^{\circ} \mathrm{C}$ ). In the case of low temperatures, the greatest decrease in productivity (13.91\%) was seen in people working at temperature below $10^{\circ} \mathrm{C}$. Extension of reaction time in both lowered and elevated temperatures was 
approximately $2.5 \%$ on average, while the biggest alertness decrease occurred in temperatures above $26.67^{\circ} \mathrm{C}$ and below $18.28^{\circ} \mathrm{C}$.

Research conducted in China [6] on a group of sixteen military industry employees indicates that a temperature increase of $1{ }^{\circ} \mathrm{C}$, according to WBGT, results in a $0.57 \%$ decrease in productivity and an increase in inactivity time by $0.74 \%$ in the case of a worker with work experience of less than 1 year. For work experience of over 1 year, these results are $0.33 \%$ and $0.72 \%$, respectively. The study was conducted during the summer months, between 7 am and $6 \mathrm{pm}$, with a four-hour gap between $11 \mathrm{am}$ and $2 \mathrm{pm}$, at the temperatures ranging from $21.71{ }^{\circ} \mathrm{C}$ to $32.11^{\circ} \mathrm{C}$. Work between 7 am and 9 am has been recognized as the most secure with the risk of adverse events between 7 am and 8 am $-3.57 \%$ and between 8 am and 9 am 7.14\%. As the most dangerous was recognized work between 2 pm and $3 \mathrm{pm}$, with a risk of $57.14 \%$.

Elevated air temperatures can also lead to various problems, from a worse physical state of the workers to serious illnesses. On 26 Hong Kong construction sites, examinations of 207 workers were conducted [7]. Thirty-six of them reported illness symptoms due to elevated temperatures. Most of them were dizziness and headache, fatigue, fever, vomiting, fainting, discomfort, difficulty in breathing, and isolated cases of unconsciousness and heat stroke. The majority of cases were in the age group between 36 and 45 years - 11 cases, and between 46 and 55 years - 11 cases as well.

Scientists try to determine activity methodology in order to reduce the risk of accidents [8], showing at the same time how many different elements influence the safety of work on scaffoldings. Human efficiency depends mainly on temperature, but also on time and type of task; body temperature and properties of protective clothes, including helmets, should be taken into consideration.

To summarize, the purpose of the article is to present the influence of temperature on the comfort of people working on scaffoldings. A simplified assumption was introduced stating that temperature is the main factor influencing work comfort and that it is independent of other variables.

\section{RESEARCH METHODOLOGY}

\subsection{IMGW data (Institute OF Meteorology ANd Water Management DATA)}

An analysis of temperature influence on the comfort of people working on scaffoldings requires data collection from many research fields. For further analysis, data collected by the IMGW (Institute of Meteorology and Water Management) and our own temperature measurements made on scaffoldings 
were chosen. For this purpose, we obtained from the IMIGW (ogimet.com website) results of temperature measurements for the same time intervals at which the scaffoldings were examined at the research stations located, respectively, in Lodz and Warsaw, from 2012-2016.

Probability $P_{m}\left(T_{i}\right)$ of the $T_{i}$ temperature occurrence for the scaffolding examination period $\mathrm{m}$ should be determined from the density distribution probability of this parameter.

\subsection{SCAFFOLDINGS MEASUREMENTS DATA}

The main data group is results of the temperature measurements on the scaffoldings [10]. These measurements were taken on ten scaffoldings, including five in Lodz and five in Warsaw or neighboring cities. Measurements were taken from April to August 2016.

A series of measurements on one scaffolding included daily, five-day long measurements from Monday to Friday at $8 \mathrm{am}, 11 \mathrm{am}$, and $2 \mathrm{pm}$, hereinafter referred as time of day, on different levels of scaffolding. The first point of measurement starts at the given time. Subsequent measurements are then performed in subsequent measurement points on the scaffolding. All measurements take about one hour. The measurement point selection criteria are set out in Table 1, while a juxtaposition with the scaffoldings and the basic measurement information is given in Table 2.

Table 1. Principles of selecting the number of measurement points depending on the size of the scaffolding

\begin{tabular}{|c|c|}
\hline $\begin{array}{c}\text { Number of } \\
\text { scaffolding fields }\end{array}$ & $\begin{array}{c}\text { Number of horizontal } \\
\text { measurement points }\end{array}$ \\
\hline 1 & 1 \\
\hline $2-4$ & 2 \\
\hline $5-8$ & 3 \\
\hline Above 9 & 4 \\
\hline
\end{tabular}

\begin{tabular}{|c|c|}
\hline $\begin{array}{c}\text { Number of working } \\
\text { platforms on scaffolding }\end{array}$ & $\begin{array}{c}\text { Number of vertical } \\
\text { measurement points }\end{array}$ \\
\hline $1-2$ & 1 \\
\hline $3-5$ & 2(first and highest level) \\
\hline Above 6 & $\begin{array}{c}\text { 3(first, middle and highest } \\
\text { level) }\end{array}$ \\
\hline
\end{tabular}

Table 2. Scaffolding numbers with basic measurements information

\begin{tabular}{|c|c|c|c|}
\hline Symbol & Examination term & Scaffolding position & $\begin{array}{c}\text { Number of measurement } \\
\text { points }\end{array}$ \\
\hline E01 & $06.06 .2016-10.06 .2016$ & north - west & 12 \\
\hline E02 & $20.06 .2016-25.06 .2016$ & north - west & 6 \\
\hline E03 & $04.07 .2016-08.07 .2016$ & north - east & 12 \\
\hline E04 & $25.07 .2016-30.07 .2016$ & south - west & 6 \\
\hline E05 & $01.08 .2016-05.08 .2016$ & south - east & 12 \\
\hline W01 & $25.04 .2016-29.04 .2016$ & north - west & 9 \\
\hline W02 & $30.05 .22016-03.06 .2016$ & south - west & 12 \\
\hline W03 & $20.06 .2016-24.06 .2016$ & north - east & 9 \\
\hline W04 & $20.06 .2016-24.06 .2016$ & south - east & \\
\hline W05 & $11.07 .2016-15.07 .2016$ & north - west & \\
\hline
\end{tabular}


The temperature was changing both according to the time of day and the working level at which the measurements were made. Measurements were made with the use of the AMI310 multifunction device, which can be connected to measuring probes, including a temperature probe. The accuracy of measurements is $\pm 0.3{ }^{\circ} \mathrm{C}$ and resolution $0.1{ }^{\circ} \mathrm{C}$.

Histograms of temperature occurrence probability for a particular construction site will be determined according to the following procedure.

The results of the construction sites examinations show that the temperature on the scaffolding also changes with height. Therefore, measurements are also separated due to the level of the scaffolding. Distribution of temperature occurrence probability $\mathrm{T}$ at time of day $i$ and on the level of scaffolding $j$ will be determined for the scaffolding as follows:

$$
P_{i j}\left(T_{k}\right)=\frac{s_{i j}\left(T_{k}\right)}{N_{i j}}
$$

where:

$N_{i j}$ - number of measurements at time of day $i$ and on the level of scaffolding $j, s_{i j}$ - number of measurements at time of day $i$ and on the level of scaffolding $j$, on which $T_{k}$ temperature occurred which is calculated using the formula:

$$
T_{k}=f\left(\frac{1}{n} \sum_{p=1}^{n} T_{p}\right)
$$

where:

$T_{p}$ - values from measurements at time of day $i$ and on the level of scaffolding $j$, n-number of measurements at time of day $i$ and on the level of scaffolding $\mathrm{j}, f(x)$ - function which takes over total values

Next, the distribution of temperature particular values occurrence probability should be determined for the entire scaffolding using the formula:

$$
P\left(T_{k}\right)=\frac{1}{n_{\text {poziom }} n_{\text {godz }}} \sum_{j=1}^{n_{\text {poziom }}} \sum_{i=1}^{n_{\text {godz }}} P_{i j}\left(T_{k}\right)
$$

where:

$n_{\text {poziom }}-$ numer of levels, $n_{\text {godz }}-$ number of time of day in which measurements were performed 


\section{TEMPERATURE SCAFFOLDING MEASUREMENTS - OUTCOMES AND}

\section{ANALYSIS}

Based on the number of environmental measurements from a study of ten scaffoldings,

the samples number was assessed. Then, the interval of the examined feature was determined according to the formula [12]:

$$
R=T_{\max }-T_{\min }
$$

where:

$T_{\max }$ - maximum temperature for specified sample, $T_{\min }$ - minimum temperature

and on the basis of the observation number, the number of classes was determined according to the formulas:

a) $k_{1}=\sqrt{n}$, b) $k_{2}=1+3,322 \ln n$, c) $k_{3}=5 \ln n$

where:

$n$ - number of observations

Tab. 3. Air temperature

\begin{tabular}{|c|c|c|c|c|c|c|c|c|}
\hline $\begin{array}{c}\text { Scaffolding } \\
\text { symbol }\end{array}$ & $\begin{array}{c}\text { Minimal } \\
\text { temperature } \\
{\left[{ }^{\circ} \mathrm{C}\right]}\end{array}$ & $\begin{array}{c}\text { Maximal } \\
\text { temperature } \\
{\left[{ }^{\circ} \mathrm{C}\right]}\end{array}$ & $\begin{array}{c}\text { Average } \\
\text { temperature } \\
{\left[{ }^{\circ} \mathrm{C}\right]}\end{array}$ & Interval & $\begin{array}{c}\text { Number of } \\
\text { observations }\end{array}$ & $\begin{array}{c}\text { Number } \\
\text { of bins } \\
k_{1}\end{array}$ & $\begin{array}{c}\text { Number } \\
\text { of bins } \\
k_{2}\end{array}$ & $\begin{array}{c}\text { Number } \\
\text { of bins } \\
k_{3}\end{array}$ \\
\hline E01 & 14.3 & 30.1 & 20.8 & 15.8 & 60 & 8 & 7 & 9 \\
\hline E02 & 17.4 & 39.0 & 25.6 & 21.6 & 34 & 6 & 6 & 8 \\
\hline E03 & 15.9 & 35.3 & 24.4 & 19.4 & 44 & 7 & 6 & 8 \\
\hline E04 & 20.6 & 37.4 & 27.2 & 16.8 & 46 & 7 & 7 & 8 \\
\hline E05 & 19.7 & 35.0 & 25.2 & 15.3 & 45 & 7 & 6 & 8 \\
\hline W01 & 9.6 & 24.8 & 15.2 & 15.2 & 27 & 5 & 6 & 7 \\
\hline W02 & 21.4 & 37.2 & 15.8 & 15.8 & 112 & 11 & 8 & 10 \\
\hline W03 & 21.2 & 45.5 & 24.2 & 24.3 & 38 & 6 & 6 & 8 \\
\hline W04 & 21.0 & 41.6 & 20.6 & 20.6 & 39 & 6 & 6 & 8 \\
\hline W05 & 18.4 & 39.5 & 21.1 & 21.1 & 86 & 9 & 7 & 10 \\
\hline
\end{tabular}


Table 3 shows the air temperature values measured on the scaffoldings. For each parameter are given: minimum, maximum, and average values, standard deviation, and the number of observations, interval, and the number of bins.

Tab. 4. Temperature distribution histograms for a) E01, b) E02, c) E03, d) E04, e) E05, f) W01, g) W02, h) W03, i) W04, j) W05

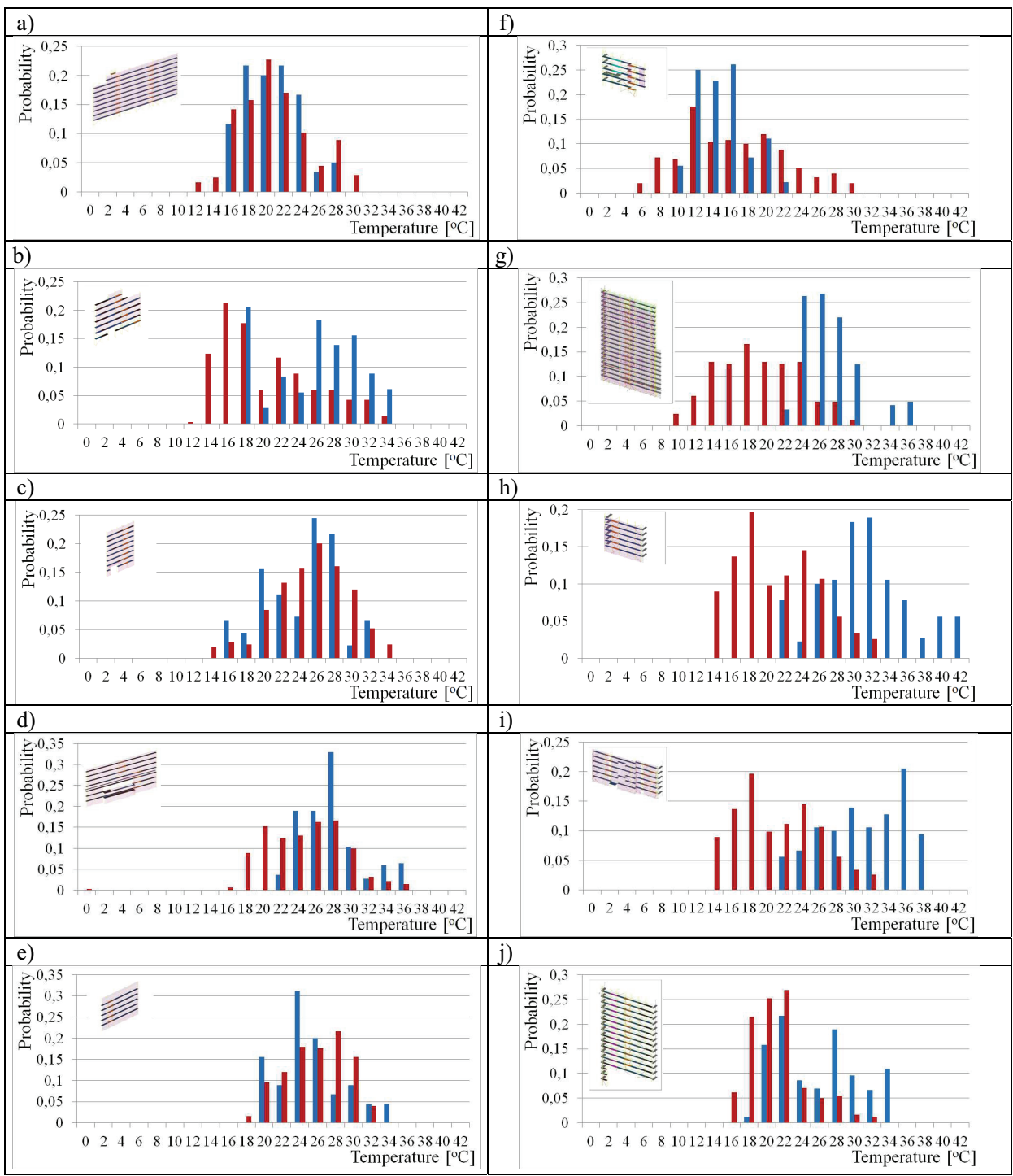


Proper selection of number and width of bins is essential for correct data analysis. Adopting too many classes may make it so that significant changes of specified values would not be visible on the histogram. Data indicated in Table 3 shows that the number of bins should fit in the range of 5 to 11 , amounting on average 7 , which corresponds to the average bin section width of $2{ }^{\circ} \mathrm{C}$.

For such adopted bin width, Table 4 shows histograms of temperature particular value occurrence probability distributions for five scaffoldings located in Lodz (E01, E02, E03, E04, E05) and five scaffoldings located in Warsaw and its surroundings (W01, W02, W03, W04, W05), marked in blue. In order to compare the obtained outcomes on the same histograms in Table 4, there have been indicated the IMIGW temperature particular value occurrence probability distributions from a fiveyear period for specified research weeks corresponding to the scaffoldings' examination terms, marked in red. Also, scaffoldings schemes are shown. Comparing the histograms based on data obtained from meteorological stations and those based on measurements made on the scaffoldings (Table 4), we can see some differences. Diagrams obtained from the measurements are shifted to higher temperatures, which can be explained by the building's impact on the temperatures of the scaffolding surroundings, to the position of the scaffolding itself, as well as to the fact that scaffolding measurements in most cases were made at much higher levels than the meteorological measurements. It should be also taken into account that the measured values, especially those measured at the highest levels, are also affected by raised construction elements temperature during sunny and warm days. The majority of probability distributions obtained for air temperature measurements on construction sites and for meteorological station measurements shows a probability value decrease in the middle of the range as a result of morning temperature jumps.

Table 5 contains temperatures occurrence probability within the thermal comfort range from $17^{\circ} \mathrm{C}$ to $21^{\circ} \mathrm{C}$ and temperatures below and above this range.

Tab. 5. Temperatures occurrence probability

\begin{tabular}{|c|c|c|c|c|}
\hline $\begin{array}{c}\text { Scaffolding } \\
\text { symbol }\end{array}$ & $\begin{array}{c}\text { Temperatures } \\
\text { occurrence probability } \\
<17^{\circ} \mathrm{C}\end{array}$ & $\begin{array}{c}\text { Temperatures occurrence } \\
\text { probability } \\
17^{\circ} \mathrm{C}-21^{\circ} \mathrm{C}\end{array}$ & $\begin{array}{c}\text { Temperatures occurrence } \\
\text { probability } \\
21^{\circ} \mathrm{C}-26^{\circ} \mathrm{C}\end{array}$ & $\begin{array}{c}\text { Temperatures } \\
\text { occurrence } \\
\text { probability }>26^{\circ} \mathrm{C}\end{array}$ \\
\hline E01 & 0.11 & 0.42 & 0.40 & 0.07 \\
\hline E02 & 0 & 0.23 & 0.23 & 0.54 \\
\hline E03 & 0.07 & 0.2 & 0.32 & 0.41 \\
\hline E04 & 0 & 0 & 0.32 & 0.68 \\
\hline E05 & 0 & 0.16 & 0.02 & 0.31 \\
\hline W01 & 0.8 & 0.18 & 0.41 & 0.56 \\
\hline W02 & 0.03 & 0 & 0.13 & 0.87 \\
\hline W03 & 0 & 0 & 0.11 & 0.89 \\
\hline W04 & 0 & 0 & 0.31 & 0.45 \\
\hline W05 & 0.08 & 0.16 & & 0.45 \\
\hline
\end{tabular}


Comparing these outcomes, it can be seen that the highest probability is at the most unfavorable temperature - above $26{ }^{\circ} \mathrm{C}$. It shows that employees are more likely to be exposed to high temperatures. The most favorable working conditions according to temperature values were on scaffolding E01, which was examined in early June. However, more disturbing is the fact that there were significant temperature differences across the whole scaffolding, reaching up to $15.9^{\circ} \mathrm{C}$. When workers change their specific position on the scaffolding, they also change the working conditions in a short burst of time, and these changes do not then allow the human body to acclimate to surrounding temperatures.

\section{SUMMARY}

On the basis of the presented research it can be said that between April and August the air temperature around most scaffoldings negatively affects work comfort. In the case of the W01 scaffolding, tested in April, the temperature was too low. In the remaining months, the workers were exposed to high temperatures during most of their working time. The most unfavorable situation was on the W04 scaffolding, where over $89 \%$ of the working time employees performed their tasks at temperatures over $26{ }^{\circ} \mathrm{C}$. Work on construction sites, especially on scaffoldings, requires a lot of physical effort and it is dangerous. That is why it is important to ensure human-friendly environmental conditions. Unfortunately, work on scaffoldings is performed outside the construction objects, and it is impossible to influence these conditions; at best, we can only monitor them. Additionally, workplace changes are associated with changes in the conditions of our surroundings, which the body is unable to adapt to easily. High temperatures and the lack of adaptability to working conditions lead to tiredness, lowered alertness levels, and are generally not good for overall health. Consequently, they lead to behaviors that can cause accidents. Therefore, workers' thermal comfort research, especially for scaffolding work on construction sites, should be further developed in the future. 


\section{REFERENCES}

1. Z. Traczyk, A. Trzebski, „Fizjologia człowieka z elementami fizjologii klinicznej i stosowanej”, PZWL, Warszawa 2004;

2. Hoła A., Hoła B., Sawicki M., Szóstak M., „Analysis of selected factors that generate the costs of accidents at work using the Polish construction industry as an example", MATEC Web of Conferences 86, 07005 (2016) IPISCE -2016

3. A. Marszałek, „Wpływ zimnego środowiska na organizm człowieka”, Bezpieczeństwo Pracy 01/2009, 10-12

4. P. A. Hancock, I. Vasmatzidis, „Human occupational and performance limits under stress: the thermal environment as a prototypical example”, Ergonomics, 1998, Vol. 41, No. 8, $1169-1191$

5. J. J. Pilcher, E. Nadler, C. Busch, „Effects of hot and cold temperature exposure on performance: a meta-analytic review”, Ergonomics, 2002, Vol. 45, No. 10, $682-698$

6. X. Li. K. H. Chow, Y. Zhu, Y. Lin, „Evaluating the impacts of high-temperature outdoor working environments on construction labor productivity in China: A case study of rebar workers", Building and Environment 95 (2016), $42-52$

7. Y. A. Jia, S. Rowlinson, M. Ciccarelli, ,Climatic and psychosocial risks of heat illness incidents on construction site", Applied Ergonomics 53 (2016) 25 - 35

8. E. Błazik-Borowa, J. Szer, „The analysis of the stages of scaffolding "life” with regard to the decrease in the hazard at building works", Archives of Civil and Mechanical Engineering 15 (2015), 516-524

9. I. Sudoł-Szopińska, A. Łuczak, „Wpływ temperatury środowiska zewnętrznego na sprawność działania człowieka", Bezpieczeństwo pracy 7-8/2006, 16-19.

10. E. Błazik-Borowa, J. Szer, „Podstawowe elementy modelu oceny ryzyka wystąpienia zdarzeń niebezpiecznych na rusztowaniach”, Przegląd budowlany 10/2016, 24-29

11. W. Krysicki, J. Bartos, W. Dyczka, K. Królikowska, M Wasilewski, „Rachunek prawdopodobieństwa i statystyka matematyczna w zadaniach”, Część I - Rachunek prawdopodobieństwa, Wydawnictwo Naukowe PWN, Warszawa 1999.

12. W. Krysicki, J. Bartos, W. Dyczka, K. Królikowska, M. Wasilewski, „Rachunek prawdopodobieństwa i statystyka matematyczna w zadaniach”, Część II - Statystyka matematyczna, Wydawnictwo Naukowe PWN, Warszawa 1999.

\section{LIST OF FIGURES AND TABLES:}

Tab. 1. Principles of selecting the number of measurement points depending on the size of the scaffolding

Tab. 1. Zasady doboru liczby punktów pomiarowych w zależności od wielkości rusztowania

Tab. 2. Scaffolding numbers with basic measurements information

Tab. 2. Schematy rusztowań z podstawowymi informacjami o pomiarach

Tab. 3. Air temperature

Tab. 3. Temperatura powietrza

Tab. 4. Temperature distribution histograms for a) E01, b) E02, c) E03, d) E04, e) E05, f) W01, g) W02,

h) W03, i) W04, j) W05

Tab. 4. Histogram rozkładu temperatury dla a) E01, b) E02, c) E03, d) E04, e) E05 f) W01, g) W02, h) W03, i) W04, j) W05

Tab. 5. Temperatures occurrence probability

Tab. 5. Prawdopodobieństwo wystąpienia temperatury 


\title{
WPLYW CZYNNIKÓW ŚRODOWISKOWYCH NA KOMFORT PRACOWNIKÓW NA PRZYKLADZIE TEMPERATURY OTOCZENIA
}

\author{
Keywords: rusztowania. bezpieczeństwo. temperatura
}

\section{STRESZCZENIE:}

Praca w niekorzystnych, zmieniających się warunkach środowiskowych, oddziałuje niekorzystnie na osoby pracujące na rusztowaniach, wykorzystywanych na budowach, mogąc zwiększać ryzyko wystąpienia sytuacji niebezpiecznych. Celem artykułu jest prezentacja wpływu temperatury na komfort pracy osób, pracujących na rusztowaniach. Wprowadzono założenie uproszczające, tzn. przyjęto, że temperatura jest głównym czynnikiem, wpływającym na komfort pracy oraz niezależnym od innych. Do dalszej analizy wybrano przede wszystkim dane wykonane przez IMGW (Instytut Meteorologii i Gospodarki Wodnej) oraz własne pomiary temperatury na rusztowaniach. W tym celu uzyskano z IMIGW (strona internetowa ogimet.com) wyniki pomiarów temperatury dla tych samych przedziałów czasowych, w których badane były rusztowania, ze stacji badawczych zlokalizowanych odpowiednio w Łodzi i Warszawie z lat 2012-2016. Główna grupa danych to wyniki pomiarów temperatury na rusztowaniu. Na dziesięciu rusztowaniach wykonano pomiary temperatury, w tym pięć w Łodzi i pięć w Warszawie lub miastach sąsiadujących z Warszawą. Pomiary wykonywano od kwietnia do sierpnia 2016 roku. Seria pomiarów na jednym rusztowaniu obejmowała pomiary przez pięć dni od poniedziałku do piątku w godz. 8.00, 11.0 i 14.00, nazywanych porami dnia, na różnych poziomach rusztowania. Pomiar w pierwszym punkcie rozpoczynał się o danej godzinie. Pomiary parametrów środowiskowych wykonywane były w czterech, sześciu, dziewięciu lub dwunastu miejscach na rusztowaniu w zależności od szerokości i wysokości rusztowania oraz od dostępności.

Temperatura zmieniała się zarówno w zależności od pory dnia jak i poziomu roboczego, na którym były wykonywane pomiary. Pomiary zostały wykonane za pomocą urządzenia wielofunkcyjnego AMI310, do którego podłączono sondy pomiarowe, w tym sondę wykonującą pomiar temperatury. $Z$ badań przeprowadzonych na budowach wynika, że temperatura na rusztowaniu zmienia się również wraz z wysokością. Dlatego pomiary zostały rozdzielone również ze względu na poziom rusztowania. Na podstawie liczby pomiarów środowiskowych z badań dziesięciu rusztowań dokonano oceny liczebności prób. Określono rozstęp badanej cechy, liczbę klas oraz długość przedziału klasowego wynoszącą $2{ }^{\circ} \mathrm{C}$. Prawidłowy dobór liczby oraz długości klas jest konieczny do prawidłowej analizy danych. Przyjęcie zbyt dużej liczby klas może spowodować, że na histogramie nie będą widoczne ważne zmiany danej wielkości. Następnie określono rozkład prawdopodobieństwa wystąpienia poszczególnych wartości temperatur dla całego rusztowania. Celem porównania otrzymanych rozkładów w artykule przedstawiono również histogramy rozkładu wystąpienia danej temperatury z IMIGW z pięciu lat dla danych tygodni badawczych odpowiadających terminom badań rusztowań.

Porównując histogramy, jakie otrzymano ze stacji meteorologicznych, z pomiarami na rusztowaniu widać pewne różnice. Wykresy otrzymane z pomiarów są bardziej przesunięte w kierunku wyższych temperatur, co może wiązać się zarówno $\mathrm{z}$ oddziaływaniem budynku na temperaturę w otoczeniu rusztowania, położeniem samego rusztowania jak również $\mathrm{z}$ pomiarami wykonywanymi w większości przypadków na dużo wyższych poziomach niż pomiary uzyskane ze stacji meteorologicznych. Należy również wziąć pod uwagę fakt, że na otrzymane wartości szczególnie te pomierzone na najwyżej położonych poziomach oddziałuje również w słoneczne i ciepłe dni podwyższona temperatura przegród. W większości rozkładów prawdopodobieństwa otrzymanych dla pomiarów temperatury powietrza na budowie oraz dla stacji 
obserwuje się obniżenie wystąpienia wartości prawdopodobieństwa w środkowej części zakresu co wynika z porannego skoku temperatury.

Na podstawie histogramów dla każdego rusztowania określono prawdopodobieństwo wystąpienia temperatury w okresie, w którym badane były rusztowania.

Prawdopodobieństwo wyznaczono w czterech przedziałach: pierwszy poniżej $17{ }^{\circ} \mathrm{C}$, drugi w zakresie komfortu termicznego od $17{ }^{\circ} \mathrm{C}$ do $21{ }^{\circ} \mathrm{C}$, trzeci od $21{ }^{\circ} \mathrm{C}$ do $26^{\circ} \mathrm{C}$ oraz czwarty dla prawdopodobieństwa wystąpienia temperatury powyżej $26^{\circ} \mathrm{C}$. Dla pierwszego przedziału największe prawdopodobieństwo otrzymano dla rusztowania W01 wynoszące 0.8. Dla przedziału w zakresie komfortu termicznego największe prawdopodobieństwo uzyskano dla rusztowania E01 wynoszące odpowiednio 0.42 , które badane było na początku czerwca. Na tym rusztowaniu panowały najbardziej korzystne warunki pracy ze względu na temperaturę. Dla trzeciego przedziału największe prawdopodobieństwo uzyskano dla E05 - 0.53, a dla przedziału powyżej $26{ }^{\circ} \mathrm{C}$, a więc tych najmniej korzystnych temperatur największe prawdopodobieństwo uzyskano dla W04 wynoszące odpowiednio 0.89. Analizując otrzymane wyniki na dziesięciu rusztowaniach można zauważyć, że największe prawdopodobieństwa występują przy najbardziej niekorzystnej temperaturze powyżej $26{ }^{\circ} \mathrm{C}$ - rusztowania E02, E04, W02, W03, W04, W05. Pracownicy narażeni są więc częściej na występowanie wysokich temperatur. Jednak bardziej niepokojący jest fakt znacznych różnic temperatur na całym rusztowaniu, dochodzących nawet do $15.9{ }^{\circ} \mathrm{C}$. Pracownicy, zmieniając miejsce pracy na rusztowaniu, zmieniają w krótkim czasie warunki pracy. Te zmiany nie pozwalają także organizmowi człowieka na klimatyzację do temperatury otoczenia.

Praca na budowach a zwłaszcza na rusztowaniach wymaga dużego wysiłku fizycznego i jest pracą niebezpieczną. Dlatego istotnym elementem jest zapewnienie warunków środowiskowych przyjaznych człowiekowi. Niestety praca na rusztowaniach jest pracą na zewnątrz obiektów i nie ma możliwości wpływania na te warunki, a jedynie można je monitorować. Dodatkowo zmiany miejsca pracy są związane ze zmianą warunków otoczenia, do których organizm nie ma możliwości adaptacji. Wysoka temperatura i brak możliwości adaptacji do warunków pracy prowadzą do zmęczenia, zmniejszenia percepcji i są niekorzystne dla zdrowia, a co za tym idzie prowadzą do zachowań wywołujących sytuacje potencjalnie wypadkowe. W związku z tym badania komfortu cieplnego pracowników szczególnie na rusztowaniach, wykorzystywanych na budowach, powinny być w przyszłości rozwijane. 